\title{
PENGENDALIAN TUNNELING DALAM ASSET UTILIZATION: SEBUAH TINJAUAN TEORITIS
}

\author{
Christian Herdinata \\ Program Studi International Business Management \\ Universitas Ciputra \\ UC Town, Citra Land, Surabaya \\ christian.herdinata@ciputra.ac.id
}

\begin{abstract}
Johnson et al. (2000) define tunneling as the transfer of resources out of the company for the benefit of controlling shareholders. This study will focus on institutional ownership and debt policy which will be further investigated as a control mechanism that occurs in asset utilization and has an impact on company performance. The results of the theoretical review of this study, namely institutional ownership and debt policy can control tunneling in asset utilization. Control mechanisms through institutional ownership of company performance can occur because institutional shareholders are very interested in company performance because a large portion of institutional shareholders' wealth is directly related to the company's wealth. The control is relevant to the owner because it is related to wealth that is tied to the company it owns, so that through increasing the proportion of institutional ownership it can reduce agency costs that arise, especially in the case of asset utilization of the company through supervision carried out. The control mechanism through debt policy on company performance can occur because the debt policy is carried out by the owner by transferring it to the banks or creditors to conduct supervision so as to maximize the performance of the company. The control becomes relevant because it is related to funds lent by banks or creditors to the company so that the company is expected to be able to pay interest and principal loans when due.
\end{abstract}

\begin{abstract}
ABSTRAK
Johnson et al. (2000) mendefinisikan tunneling sebagai transfer sumber daya keluar dari perusahaan untuk kepentingan pemegang saham pengendali. Penelitian ini akan memfokuskan pada kepemilikan institusional dan kebijakan utang yang akan diteliti lebih lanjut sebagai mekanisme kontrol yang terjadi dalam asset utilization dan berdampak pada kinerja perusahaan. Hasil dari tinjauan teoritis dari penelitian ini yaitu kepemilikan institusional dan kebijakan utang dapat mengendalikan tunneling dalam asset utilization. Mekanisme kontrol melalui kepemilikan institusional terhadap kinerja perusahaan dapat terjadi karena pemegang saham institusional sangat berkepentingan dengan kinerja perusahaan karena sebagian besar kekayaan pemegang saham institusional terkait langsung dengan kekayaan perusahaan. Pengendalian tersebut menjadi relevan dilakukan
\end{abstract}


oleh pemilik karena terkait dengan kekayaan yang terikat dengan perusahaan yang dimilikinya, sehingga melalui peningkatan proporsi kepemilikan institusional dapat mengurangi biaya keagenan yang muncul khususnya pada asset utilization yang dimiliki perusahaan melalui pengawasan yang dilakukan. Mekanisme kontrol melalui kebijakan utang terhadap kinerja perusahaan dapat terjadi karena kebijakan utang dilakukan oleh pemilik dengan memindahkan kepada pihak perbankan atau kreditur untuk melakukan pengawasan sehingga dapat memaksimalkan kinerja perusahaan. Pengendalian tersebut menjadi relevan karena terkait dengan dana yang dipinjamkan oleh pihak perbankan atau kreditur kepada perusahaan sehingga diharapkan perusahaan mampu membayar bunga dan pokok pinjaman ketika jatuh tempo.

Keywords: tunneling, asset utilization, institutional ownership, debt policy.

\section{PENDAHULUAN}

Johnson et al. (2000) mendefinisikan tunneling sebagai transfer sumber daya keluar dari perusahaan untuk kepentingan pemegang saham pengendali. Transaksi pihak berelasi yang terindikasi tunneling, antara lain: (1) transaksi pembayaran kas; (2) pembelian aset; (3) penjualan aset; dan (4) tukar-menukar aset (Cheung et al., 2006a; Cheung et al., 2009a). Karena melibatkan pihak pemegang saham pengendali, maka masalah tunneling tidak mudah untuk diketahui dan ditangani.

Berdasarkan permasalahan tersebut, maka tunneling dalam pemanfaatan aset (asset utilization) dapat menjadi masalah dalam perusahaan apabila tidak diselesaikan dengan mekanisme yang benar dan tidak menemukan solusi yang tepat, bahkan akan berpengaruh pada kinerja perusahaan. Oleh karena itu, penelitian mengenai mekanisme pengendalian terhadap asset utilization dalam menemukan solusi yang tepat menjadi penting. Tulisan ini secara khusus membahas tentang tunneling yang terjadi melalui asset utilization dan mekanisme yang digunakan untuk mengendalikannya.

\section{TINJAUAN PUSTAKA}

Penelitian empiris berkaitan dengan mekanisme pengendalian untuk menyelesaikan isu konflik keagenan dilakukan oleh beberapa peneliti, antara lain: Jensen dan Meckling (1976) menunjukkan bahwa penggunaan utang dapat membantu mengurangi masalah keagenan antara manajer dan pemegang saham. Jensen (1986) menunjukkan bahwa mekanisme penggunaan utang dapat mengurangi masalah keagenan karena overinvestment. Kim and Sorenson (1986), Long and Malitz (1985), Friend and Lang (1988) menemukan bahwa keputusan untuk menaikkan utang konsisten dengan penurunan biaya keagenan. Jensen et al. (1992) menguji tiga keputusan keuangan yaitu leverage, dividen, dan kepemilikan insider dalam sistem simultan. Mereka menemukan bahwa utang dan dividen tampaknya dipilih secara bersamaan untuk mengurangi biaya keagenan, namun mereka tidak menemukan bukti bahwa kepemilikan insider merupakan pengganti utang 
dan dividen dalam mengendalikan biaya keagenan.

Selanjutnya, Bathala et al. (1994) menguji sistem simultan dari kepemilikan insider, leverage, dan kepemilikan institusional sebagai variabel independen. Mereka menemukan kepemilikan institusional bertindak sebagai subtitusi untuk kepemilikan manajerial dan leverage. Chen and Steiner (1999) menunjukkan bahwa leverage, kepemilikan manajerial, dividen, dan risiko memiliki efek subtitusi serta antara kepemilikan institusional dan kepemilikan manajerial. Berdasarkan penelitian empiris tersebut, maka terdapat empat variabel yang dapat digunakan sebagai mekanisme kontrol untuk mengendalikan biaya keagenan, yaitu: kepemilikan manajerial, kepemilikan institusional, kebijakan utang, kebijakan dividen.

Berdasarkan karakteristik kondisi perusahaan di Indonesia bahwa jumlah kepemilikan manajerial semakin lama semakin kecil. Herdinata et al. (2013) meneliti dari 134 perusahaan non keuangan yang telah diaudit sejak tahun 2000-2011 bahwa rata-rata perusahaan yang memiliki kepemilikan manajerial hanya sekitar 32 perusahaan per tahun, sehingga kepemilikan manajerial relatif sulit digunakan sebagai variabel dari mekanisme kontrol dalam penelitian di Indonesia. Selain itu, kebijakan dividen juga relatif sulit digunakan karena data dividen di Indonesia yang relatif sedikit, sehingga kurang terintegrasi dengan kebijakan keuangan perusahaan. Herdinata et al. (2013) meneliti dari 134 perusahaan non keuangan yang telah diaudit sejak tahun 2000-2011 bahwa rata-rata perusahaan yang membagikan dividen hanya sekitar 52 perusahaan per tahun. Penerapan mekanisme kontrol melalui kepemilikan institusional yaitu dengan melakukan pengawasan, sehingga dapat mengurangi biaya keagenan untuk memaksimalkan kinerja perusahaan. Pengawasan tersebut menjadi relevan dilakukan oleh pemilik karena terkait dengan kekayaan yang terikat dengan perusahaan yang dimilikinya, sehingga melalui peningkatan proporsi kepemilikan institusional dapat mengurangi biaya keagenan yang muncul khususnya pada asset utilization yang dimiliki perusahaan melalui pengawasan yang dilakukan. Hal yang menarik untuk diteliti lebih lanjut yaitu kepemilikan pada tingkat tertentu ternyata dapat sejalan dengan peningkatan kinerja perusahaan (convergence hyphothesis), tetapi dapat juga terjadi penyimpangan dengan kinerja perusahaan (entrenchment hyphothesis).

Proporsi kepemilikan institusional yang semakin tinggi menyebabkan pemegang saham mayoritas memiliki kontrol. Hal tersebut mengakibatkan pemegang saham mayoritas memiliki otoritas secara lebih dekat untuk mengawasi perusahaan dan pihak manajemen sehingga memberikan pengaruh positif, tetapi sebaliknya pemegang saham mayoritas juga berpotensi untuk berkonflik dengan pemegang saham lain, khususnya pemegang saham minoritas (Surya dan Yustiavandana, 2006). Konflik ini akan memberikan akibat buruk ketika pemegang saham mayoritas melakukan eksploitasi perusahaan yang dikontrolnya dengan biaya yang juga ditanggung para pemegang saham lain, khususnya para pemegang saham minoritas sehingga dapat menurunkan kinerja perusahaan. Oleh karena itu, menjadi penting untuk diteliti pada perusahaan di Indonesia yaitu mengarah kepada convergence hyphothesis atau entrenchment hypho- 
thesis dalam hubungan antara kepemilikan institusional dengan asset utilization sebagai bagian dari kinerja perusahaan.

Penelitian di Indonesia yang telah dilakukan oleh Mahadwartha (2004) mendapatkan temuan mendukung convergence hyphothesis, yang berbeda dengan temuan Hermeindito (2009) yang mendukung entrenchment hyphothesis. Oleh karena itu, perlu penelitian lebih lanjut untuk membuktikan perbedaan efek dan hubungan non linier antara kepemilikan institusional terhadap asset utilization dan kinerja perusahaan. Selain itu, penelitian ini juga berbeda dengan penelitian Mahadwarta (2004) dan Hermeindito (2009), karena penelitian ini mempertimbangkan asset utilization yang belum banyak dilakukan untuk model pengujian dalam mekanisme kontrol yang tidak digunakan oleh peneliti sebelumnya. Penelitian ini mempertimbangkan peran mekanisme kontrol dari kepemilikan institusional terhadap ekspropriasi yang terjadi pada asset utilization melalui tunneling yang berpengaruh pada kinerja perusahaan dan belum banyak teliti.

Di sisi lain, penggunaan utang dapat memberikan keuntungan bagi perusahaan karena beban bunga yang dibayarkan dapat mengurangi pendapatan yang terkena pajak sehingga menghemat pembayaran pajak. Namun jika pengunaan utang semakin tinggi dapat menyebabkan risiko kebangkrutan. Hal ini tercermin dari trade-off antara manfaat utang melalui penghematan pajak dan risiko perusahaan untuk memberikan nilai yang optimal bagi perusahaan dan hal ini dikenal sebagai trade-off theory (Bringham et al., 1999). Oleh karena itu, menjadi penting untuk diteliti pada perusahaan di Indonesia, yaitu mendukung tradeoff theory atau tidak.

Modigliani and Miller (1963) mengoreksi asumsi tanpa pajak menjadi model dengan mempertimbangkan pajak perusahaan. Koreksi asumsi ini membawa implikasi pada perubahan proposisi bahwa semakin tinggi utang semakin tinggi nilai perusahaan sehingga tidak mendukung trade-off theory. Namun, sejumlah peneliti menujukkan dukungannya terhadap trade-off theory (Sabiswalsky, 2010; Hackbarth et al., 2007; Myers, 2003; Hermeindito, 2002; Rajan and Zingales, 1995). Oleh karena itu, perlu penelitian lebih lanjut untuk membuktikan perbedaan efek dan hubungan non linier antara kebijakan utang terhadap asset utilization dan kinerja perusahaan. Selain itu, penelitian ini mempertimbangkan peran mekanisme kontrol dari kebijakan utang terhadap ekspropriasi yang terjadi pada asset utilization melalui tunneling yang berpengaruh pada kinerja perusahaan dan belum banyak diteliti.

\section{PEMBAHASAN}

Penelitian ini memfokuskan pada kepemilikan institusional dan kebijakan utang yang akan diteliti lebih lanjut sebagai mekanisme kontrol yang terjadi dalam asset utilization dan berdampak pada kinerja perusahaan. Oleh karena itu, penelitian ini berfokus pada mekanisme kontrol yang terjadi karena ekspropriasi melalui tunneling yang terjadi pada perusahaan untuk dilakukan mekanisme kontrol. Mekanisme kontrol melalui kepemilikan institusional dan kebijakan utang terhadap asset utilization akan berpengaruh pada peningkatan kinerja. Asset utilization dalam perusahaan yang dapat dikelola secara 
optimal akan meningkatkan produktivitas perusahaan sehingga kinerja perusahaan menjadi meningkat. Oleh karena itu, hal terpenting yang perlu dilakukan yaitu bagaimana memonitor terhadap asset utilization. Penelitian Iskandar et al. (2012) menemukan bahwa kepemilikan yang terkonsentrasi berpengaruh positif terhadap asset utilization. Hasil penelitian tersebut menunjukkan bahwa perusahaan dengan kepemilikan yang terkonsentrasi memiliki kepentingan untuk memanfaatkan aset secara optimal sehingga ketika perusahaan mampu memanfaatkan aset tersebut maka kinerja perusahaan akan meningkat dan pemilik akan memperoleh keuntungan, demikian sebaliknya.

Mekanisme kontrol dapat dilakukan pada asset utilization melalui kepemilikan institusional dan kebijakan utang untuk mengendalikan konflik keagenan yang terjadi sehingga kinerja perusahaan dapat meningkat. Pola mekanisme kontrol yang terjadi antara kepemilikan institusional dan kebijakan utang dapat berupa hubungan substitusi atau komplementer. Hubungan substitusi terjadi ketika kebijakan yang diambil perusahaan untuk mengendalikan konflik keagenan dapat dilakukan dengan menggunakan salah satu kebijakan yaitu berdasarkan kepemilikan institusional atau kebijakan utang, sedangkan hubungan komplementer terjadi ketika kebijakan yang diambil perusahaan untuk mengendalikan konflik keagenan dilakukan secara bersama-sama untuk saling melengkapi, yaitu berdasarkan kepemilikan institusional dan kebijakan utang.

Mekanisme kontrol melalui kepemilikan institusional terhadap kinerja perusahaan dapat terjadi karena pemegang saham institusional sangat berkepentingan dengan kinerja perusahaan sebab sebagian besar kekayaan pemegang saham institusional terkait langsung dengan kekayaan perusahaan. Ketika proporsi kepemilikan (ownership) pemegang saham pengendali rendah maka ia akan melakukan ekspropriasi terhadap pemegang saham minoritas dengan kontrol yang dimiliki karena pemegang saham pengendali merupakan pihak yang hanya sedikit merasakan pengaruh negatif dari penurunan nilai perusahaan atas tindakan ekspropriasi tersebut karena kepemilikannya yang rendah. Hal tersebut sejalan dengan argumen Negative Entrenchment Effect (NEE) yang dikemukakan oleh Siregar (2006) yaitu pemegang saham pengendali menggunakan kemampuannya mengendalikan manajemen untuk kepentingan pribadi dengan melakukan ekspropriasi terhadap pemegang saham minoritas.

Di sisi lain, ketika proporsi kepemilikan (ownership) pemegang saham pengendali tinggi maka ia tidak akan melakukan ekspropriasi terhadap pemegang saham minoritas karena pemegang saham pengendali merupakan pihak yang paling merasakan pengaruh negatif dari penurunan nilai perusahaan atas tindakan ekspropriasi tersebut karena kepemilikannya yang tinggi, sehingga kepemilikan yang tinggi dapat menjadi mekanisme kontrol. Hal tersebut sejalan dengan argumen Positive Incentive Effect (PIE) yang dikemukan oleh Siregar (2006) bahwa pemegang saham pengendali memonitor manajemen dengan tujuan untuk peningkatan nilai perusahaan dan menghindari terjadinya ekspropriasi. Oleh karena itu pengaruh kepemilikan institusional terhadap kinerja perusahaan pada 
tingkat tertentu adalah negatif, tetapi ketika kepemilikan institusional semakin tinggi menjadi positif.

Selanjutnya, mekanisme kontrol yang dilakukan kepemilikan institusional terhadap asset utlilization yaitu seiring dengan meningkatnya kepemilikan institusional dalam perusahaan, maka mekanisme kontrol yang dilakukan terhadap perusahaan juga meningkat, sehingga asset utilization meningkat (positif). Namun, ketika konsentrasi kepemilikan mencapai tingkat tertentu yang semakin tinggi, maka moral hazard yang mereka lakukan juga meningkat dan cenderung menggunakan kekuatannya untuk menguntungkan diri mereka sendiri dengan melakukan ekspropriasi melalui tunneling sehingga asset utilization menurun (negatif). Berdasarkan penjelasan tersebut maka hubungan antara kepemilikan institusional dan asset utilization mengarah kepada entrenchment hyphothesis.

Beberapa penelitian telah dilakukan tetapi dalam pengujian secara linier menemukan hasil yang berbeda. Jelinek and Stuerke (2009) dan Iskandar et al. (2012) menemukan bahwa pengaruh kepemilikan institusional terhadap asset utilization adalah negatif. Di sisi lain, Ang et al. (2000) dan Ade (2007) menemukan bahwa pengaruh kepemilikan institusional terhadap asset utilization adalah positif. Berdasarkan penjelasan yang ada, maka penting untuk mengkaji pola hubungan kepemilikan institusional dalam penerapan mekanisme kontrol untuk mengendalikan konflik keagenan yang berpengaruh pada asset utilization.

Mekanisme kontrol melalui kebijakan utang terhadap kinerja perusahaan dapat terjadi karena kebijakan utang dilakukan oleh pemilik dengan memindahkan kepada pihak perbankan atau kreditur untuk melakukan pengawasan sehingga dapat memaksimalkan kinerja perusahaan. Pengawasan tersebut menjadi relevan karena terkait dengan dana yang dipinjamkan oleh pihak perbankan atau kreditur kepada perusahaan sehingga diharapkan perusahaan mampu membayar bunga dan pokok pinjaman ketika jatuh tempo. Oleh karena itu, semakin tinggi kebijakan utang maka mekanisme kontrol yang dilakukan melalui kebijakan utang semakin kuat sehingga kinerja perusahaan meningkat karena konflik keagenan yang rendah sehingga menimbulkan biaya keagenan yang relatif kecil.

Di sisi lain, ketika kebijakan utang semakin tinggi maka dapat terjadi trade-off antara biaya pengawasan yang ditanggung melalui utang dengan biaya kewajiban karena beban bunga dan pokok pinjaman yang semakin besar ditanggung oleh perusahaan sehingga pemegang saham institusional berusaha menjaga tingkat biaya pengawasan yang optimal dalam melakukan mekanisme kontrol melalui kebijakan utang. Jensen and Meckling (1976) mengungkapkan bahwa pemilik modal utang dan ekuitas berkepentingan terhadap pengawasan para manajer yang mengelola modal dan aset yang mereka miliki. Oleh karena itu pengaruh kebijakan utang terhadap kinerja perusahaan pada tingkat tertentu adalah positif, tetapi ketika kepemilikan institusional semakin tinggi menjadi negatif.

Selanjutnya, mekanisme kontrol melalui kebijakan utang terhadap asset utilization dapat terjadi karena pihak perbankan atau kreditur sangat berkepentingan terhadap asset utilization karena sebagian besar dana pinjaman 
diberikan oleh pihak perbankan atau kreditur kepada perusahaan atau debitur. Oleh karena itu, ketika utang rendah hingga moderat maka mekanisme kontrol yang dilakukan oleh pihak perbankan atau kreditur cenderung lemah terhadap asset utilization sehingga ekspropriasi meningkat, tetapi pada saat utang tinggi maka mekanisme kontrol yang dilakukan oleh pihak perbankan atau kreditur cenderung kuat terhadap asset utilization sehingga ekspropriasi menurun.

Pada saat pihak pemilik perusahaan mulai menggunakan utang yang masih relatif rendah maka terjadi ekspropriasi yang dilakukan oleh pemilik terhadap pihak perbankan atau kreditur melalui tunneling terhadap aset perusahaan karena pihak kreditur atau perbankan masih memiliki kontrol yang lemah sehingga menyebabkan asset utilization menurun (negatif). Selanjutnya ketika utang digunakan semakin tinggi oleh pihak pemilik perusahaan maka kontrol pihak perbankan atau kreditur terhadap perusahaan semakin kuat dilakukan sehingga pihak pemilik akan berusaha menggunakan asset perusahaan dengan optimal sehingga asset utilization perusahaan meningkat (positif).

Berdasarkan penjelasan tersebut maka hubungan antara kebijakan utang dan asset utilization mengarah kepada trade-off antara manfaat utang sebagai mekanisme kontrol dan risiko kegagalan dalam membayar kewajiban berupa beban bunga dan pokok pinjaman yang harus dibayar. Beberapa penelitian telah dilakukan tetapi dalam pengujian secara linier menemukan hasil yang berbeda. Jelinek and Stuerke (2009) dan Iskandar et al. (2012) menemukan bahwa pengaruh kebijakan utang terhadap asset utilization adalah negatif. Di sisi lain, Ang et al. (2000) dan Ade (2007) serta Wang (2010) menemukan bahwa pengaruh kebijakan utang terhadap asset utilization adalah positif. Berdasarkan penjelasan yang ada, maka penting untuk mengkaji pola hubungan kebijakan utang dalam penerapan mekanisme kontrol untuk mengendalikan konflik keagenan sehingga asset utilization dapat meningkat dan berpengaruh pada kenaikkan kinerja perusahaan.

\section{SIMPULAN}

Pengaruh dari penerapan mekanisme kontrol terhadap asset utilization dan kinerja perusahaan yaitu konflik keagenan yang terjadi dapat menjadi semakin rendah. Hal ini sangat dipengaruhi oleh mekanisme kontrol yang dilakukan oleh perusahaan. Pada saat mekanisme kontrol berjalan dengan efektif melalui kepemilikan institusional dan kebijakan utang maka asset utilization dan kinerja perusahaan menjadi meningkat. Hal ini menunjukan bahwa konflik keagenan cenderung rendah sebagai pengaruh dari penerapan mekanisme kontrol yang efektif. Di sisi lain, Pada saat mekanisme kontrol tidak berjalan dengan efektif melalui kepemilikan institusional dan kebijakan utang yang semakin rendah maka asset utilization dan kinerja perusahaan menjadi menurun. Hal ini menunjukan bahwa konflik keagenan cenderung tinggi sebagai pengaruh dari penerapan mekanisme kontrol yang tidak efektif.

\section{SARAN}

Berdasarkan hal tersebut maka pengujian pengaruh asset utilization terhadap kinerja perusahaan penting dilakukan untuk mengetahui apakah peningkatan asset utilization yang 
tinggi sejalan dengan peningkatan kinerja perusahaan yang tinggi sehingga dapat membuktikan apakah telah terjadi tunneling pada perusahaan. Di sisi lain, penerapan mekanisme kontrol yang dilakukan melalui kepemilikan institusional dan kebijakan utang dalam memberikan solusi untuk mengendalikan konflik keagenan yang terjadi karena ekspropriasi melalui tunneling perlu dibuktikan. Oleh karena itu, penting untuk mengkaji pola hubungan antara kepemilikan institusional dan kebijakan utang dalam melakukan mekanisme kontrol terhadap konflik keagenan sehingga asset utilization dapat dikelola dengan benar dan kinerja perusahaan dapat meningkat.

\section{DAFTAR KEPUSTAKAAN}

Abor, Joshua, 2007, Debt Policy and Performance of SMEs, Evidence from Ghanaian and South African Firms, The Journal of Risk Finance, Vol. 8, No. 4, page 364-379.

Adam, T. and V. K. Goyal, 2008, The Investment Oppurtunity Set and Its Proxy Variables, The Journal of Financial Research, Vol. 11, page 41-63.

Ade, Yustina, 2008, Hubungan Struktur Kepemilikan dan External Monitoring Terhadap Agency Cost dan Aliran Kas, Jurnal Keuangan dan Perbankan, Vol. 12, No. 3, hal. 343-354.

Aharony, J., J. Wang and H. Yuan, 2005, Related Party Transaction: A Real Means of Earning Management and Tunneling during IPO Process in China, Working Paper, University of Tel Aviv.
Ang, J. S., R. A. Cole and W. J. Lin, 2000, Agency Cost and Ownership Structure, Journal of Finance, 55, page 81-106.

Arosa, Blanca, Txomin Iturralde and Amaia Mased, 2009, Ownership Structure and Firm Performance in Non-Listed Firms: Evidence from Spain, University of the Basque Country, UPV/EHU, Spain.

Atasanov, Black, Ciccotello and Gyoshev, 2007, How Does Law Affect Finance An Examination of Financial Tunneling in an Emerging Market, Law and Economics Workshop, page 1-64.

Baskin, J., 1989, An Empirical Investigation of the Pecking Order Hypothesis, Financial Management, page 26-35.

Bathala, C. T., K. P. Moon and R. P. Rao, 1994, Managerial Ownership, Debt Policy and The Impact of Institutional Holdings: An Agency Perspective, Financial Management, page 38-50.

Baxter, N. D., 1967, Leverage, Risk of Ruin and the Cost of Capital, Journal of Finance, page 395-403.

Beiner, Stefan, Wolfgang Drobetz, Markus M. Schmid, and Heinz Zimmermann, 2006, Anintegrated Framework of Corporate Governance and Firm Valuation, European Financial Management, Vol. 12, Isuuse 2, page 249-283.

Black, Fisher and Mayron S. Scholes, 1974, The Effect of Dividend Yield and Dividend Policy on Common Stocks Prices and Returns, Journal of Financial Economics, page 1-21. 
Bos, Pendleton and Toms, 2011, Governance Thresholds, Managerial Ownership and Corporate Performance: Evidence from the U.K., Working Paper, No 58.

Bozec, Y. and C. Laurin, 2008, Large Shareholder Entrenchment and Performance: Empirical Evidence from Canada, Journal of Business Finance \& Accounting, 35, page 25-49.

Brickley, J. A, C. L. Ronald, and C. W. Smith, 1988, Ownership Atructure and Voting on Anti Take over Amendments, Journal of Financial Economics, 20, page 267291.

Bringham, E. F., L. C. Gapenski and P. R. Dave, 1999, Intermediate Financial Management, $8^{\text {th }}$ Edition, Thomson Corporation, South Western.

Burkart, Mike, D. Gromb, and Fausto Panunzi, 1997, Large Shareholders, Monitoring, and The Value of The Firm, The Quaterly Journal of Economics, page 693-728.

Burkart, Mike, Fausto Paununzi and Andrei Shleifer, 2003, Family Firms, Journal of Finance, Vol. 58, No. 5, page 2167-2201.

Byers, S. S., L. P. Fields and D. R. Fraser, 2008, Are Corporate Governance and Bank Monitoring Substitutes: Evidence from The Perceived Value of Bank Loans, Journal of Corporate Finance, 14, page 475-483.

Carvalhal-da-Silva and Leal, 2000, Ownership, Control and Corporate Valuation of Brazilian Companies,
Proceedings of the Latin American Corporate Governance Roundtable, Sao Paulo.

Chan, Wesley S., 2001, Stock Price Reaction to News and No-News: Drift and Reversal After Headlines.

Chen, C. R. and T. L. Steiner, 1999, Managerial Ownership and Agency Conflicts: A Non Linear Simultaneous Equation Analysis of Managerial Ownership, Risk Taking, Deb Policy and Dividend Policy, The Financial Review, 34, page 119-136.

Chen, J., 2001, Ownership Structure as Corporate Governance Mechanism: Evidence from Chinese Listed Companies, Economic of Planning, 34, page 53-72.

Chen, J., D. H. Chen and P. He, 2008, Corporate Governance, Control Type and Performance: The New Zealand Story, Corporate Ownership and Control, 2, page 24-35.

Cheung, Y., P. R. Rau and A. Stouraitis, 2006a, Tunneling, Propping and Expropriation: Evidence from Connected Party Transaction in Hongkong, Journal of Financial Economic, 82, page 343-386.

Cheung, W., K. Adrian and K. C. John Wei, 2006b, Insider Ownership and Corporate Performance: Evidence from The Adjustment Cost Approach, Journal of Corporate Finance, 12, page 906-925.

Cheung, Yan-Leung, Y. H. Qi and P. Raghavendra Rau, 2009a, Buy High, Sell Low: How Listed Firms Price Asset Transfers in Related 
Party Transactions, Journal of Banking and Finance, Vol. 33, No. 5, page 914-924.

Cheung, Yan-Leung, Lihua Jing, Tong Lu, P. Raghavendra Rau and Aris Stouraitis, 2009b, Tunneling and Propping up: An Analysis of Related Party Transactions by Chinese Listed Companies, PacificBasin Finance Journal, Vol. 17, No. 3, page 372-393.

Chowdhury, Anup and Suman Paul Chowdhury, 2010, Impact of Capital Structure on Firm's Value: Evidence from Bangladesh, BEH Business and Economic Horizons Volume 3, Issue 3, page 111-122.

Claessens, Stijn, Simeon Djankov and Larry H. P. Lang, 1999, Who Controls East Asian Corporations, Working Paper 2054, World Bank.

Claessens, Stijn, Simeon Djankov and Larry H. P. Lang, 2000, The Separation of Ownership and Control in East Asian Corporations, Journal of Financial Economics, 58, page 81-112.

Claessens, Stijn and J. P. H. Fan, 2002, Corporate Governance in Asia: A Survey, International Review of Finance, 3, page 71-103.

Cole and Mehran, 1998, The Effect of Changes in Ownership Structure on Performance: Evidence from The Thrift Industry, Journal of Financial Economic, 50, page 291-317.

Cooper, D. R. and P. S. Schindler, 2011, Business Research Methods, Eleventh Edition, McGraw-Hill.

Crutchley, C. E., M. R. H. Jensen, J. S. Jahera and J. E. Raymond, 1999,
Agency Problem and The Simultaneity of Financial Decision Making: The Role of Institutional Ownership, International Review of Financial Analysis 8/2, page 177197.

Cui and Mak, 2002, The Relationship Between Managerial Ownership and Firm Performance in High $R \& D$ Firms, Journal of Corporate Finance 8, page 313-336.

Davies, J. R., David Hiller and Patrick McColgan, 2005, Ownership Structure, Managerial Behavior and Corporate Value, Journal of Corporate Finance, 11, page 645660.

DeAngelo, H. and R. W. Masulis, 1980, Optimal Capital Structure Under Corporate and Personal Taxation, Journal of Financial Economics, 8, page 3-29.

De Miguel, Pindado and De La Torre, 2003, Ownership Structure and Firm Value: New Evidence from the Spanish Corporate Governance System.

Douma, S., R. George and R. Kabir, 2006, Foreign and Domestic Ownership, Business Groups and Firm Performance: Evidence from A Large Emerging Market, Strategic Management Journal, 27, page 637-657.

Duggal, Rakesh and James A. Millar, 1999, Institusional Ownership and Firm Performance: The Case of Bidder Return, Journal of Corporate Finance, 5, page 103-117.

Durnev and E. Han Kim, 2005, To Steal or Not to Steal: Firm 
Attributes, Legal Environment and Valuation, Journal of Finance, Vol. 60 , Issue 3, page 1461-1493.

Ellis, R., 1998, Asset Utilization: A Metric for Focusing Reliability Efforts, Seventh International Conference on Process Plant Reliability, Marriot Houston Westside Houston, Texas, page 25-30.

Faccio and Lasfer, 1999, Managerial Ownership, Board Structure and Firm Value: The UK Evidence, Bilkent University and Hacettepe University, Turkey.

Faccio, Mara, Larry H. P. Lang and Leslie Young, 2001, Dividends and Ex-propriation, American Economic Review, Vol. 91, page 54-78.

Faisal, 2013, Mekanisme Pengendalian Konflik Keagenan antara Pemegang Saham Mayoritas dan Minoritas: Studi Empiris Di Bursa Efek Indonesia, Disertasi, Pascasarjana Universitas Gadjah Mada.

Fleming, G., Richard Heaney and R. McCosker, 2005, Agency Cost and Ownership Structure in Australia, Pacific-Basin Finance Journal, 13, page 29-52.

Friend, Irwin and Larry H. P. Lang, 1988, An Empirical Test of the Impact of Managerial Self-Interest on Corporate Capital Structure, Journal of Finance, 43, page 271282.

García-Meca, Emma and Juan P. Sanchez-Ballesta, 2009, Corporate Governance and Earnings Management: A Meta-Analysis, Corporate Governance: An International Review, 17 (5), page 594-561.
Gedajlovic, E. and D. Shapiro, 2002, Ownership and Firm Profitability in Japan, Academy of Management Journal, 45, page 575-585.

Greene, William H., 2000, Econometric Analysis, Fourth Edition, Prentice Hall Inc., Upper Saddle River, New Jersey.

Grossman, S. J. and O. D. Hart, 1982, Corporate Financial Structure and Managerial Incentives, National Bureu of Economic Research (NBER), Working Paper, No. R 0398, page 107-140.

Gujarati, Damodar N., 2003, Basic Econometrics, Fourth Edition, McGraw-Hill, Boston.

Gujarati, Damodar N. and Dawn C. Porter, 2012, Dasar-Dasar Ekonometrika, Edisi 5, Salemba Empat, Jakarta.

Gursoy, Guner and Aydogan Kursat, 1999, Equity Ownership Structure, Risk Taking and Performance: An Empirical Investigation in Turkish Companies, Working Paper, Faculty of Business Administration, Bilkent University, Bilkent, 06533 Ankara, Turkey.

Hackbarth, D., C. A. Hennessy and H. E. Leland, 2007, Can The Trade-off Theory Explain Debt Structure? Review of Financial Studies, 20, page 1389-1428.

Harris, M. and A. Raviv, 1990, Capital Structure and The Information Role of Debt, Journal of Finance, page 321-349.

Herdinata, Christian, 2006, ESOP (Employee Stock Ownership Program) Terhadap Reaksi Pasar 
dan Hubungannya dengan Kinerja Perusahaan yang Go Public Di Bursa Efek Jakarta, Tesis, Pascasarjana Universitas Kristen Satya Wacana, Salatiga.

Herdinata, Christian, 2012, Reaksi Pasar Terhadap Pengumuman ESOP (Employee Stock Ownership Program), Jurnal Keuangan dan Perbankan, hal. 77-85.

Herdinata, Christian dan C. Christian Efrata, 2013, Kepemilikan Institusional dan Aliran Kas Bebas: Studi Empiris Dalam Perspektif Agency Theory, Proceeding, Fakultas Ekonomi Universitas Kristen Maranatha.

Hermeindito, 2002, Financing Decision Relevancy: An Emphirical Evidence of Balancing Theory, Jurnal Ekonomi dan Bisnis, Vol. 2, No. 1, Universitas Katolik Atma Jaya, Jakarta, hal. 13-20.

Hermeindito, 2004, Informasi Asimetri dan Kontrol Manajemen: Analisis Kepekaan Investasi dan Leverage Terhadap Pemilihan Sumber-Sumber Pendanaan, Disertasi, Pascasarjana Universitas Gadjah Mada.

Hermeindito, 2009, Saling Keterkaitan antara Struktur Kepemilikan, Kebijakan Utang, dan Dividen dengan Kinerja Perusahaan dalam Perspektif Keagenan, Hibah Penelitian PHK A3, Universitas Katolik Widya Mandala Surabaya.

Hermeindito, 2012, Leverage dan Nilai Perusahaan: Studi Empiris Pengujian Teori Pertukaran dan Teori Keagenan, Laporan Penelitian, Universitas Katolik Widya Mandala Surabaya.
Heugens, P. P. M. A. R., M. V. Essen and J. H. V. Osterhou, 2009, MetaAnalyzing Ownership Concentration and Firm Performance in Asia: Towards A More Fine-grained Understanding, Asia Pac J Manag, 26, page 481-512.

Hu, Y. and S. Izumida, 2008, The Relationship Between Ownership and Performance: A Review of Theory and Evidence, International Business Research, 1, page 72-81.

Huang, Lin and Huang, 2011, The Influences of Ownership Structure: Evidence from China, Journal of Developing Areas is the property of Tennessee State University, College of Business.

Imam, M. O. and M. Malik, 2007, Firm Performance and Corporate Governance Through Ownership Structure: Evidence from Bangladesh Stock Market, International Review of Business Research Papers, 3, page 88-110.

Iskandar Mohd Takiah, Bukit Br Rina and Sanusi Mohd Zuraidah, 2012, The Moderating Effect of Ownership Structure on The Relationship Between Free Cash Flow and Asset Utilization, Asian Academy of Management, Journal of Accounting and Finance, Vol. 8, No. 1, page 69-89.

Ismiyanti, F., 2003, Kepemilikan Manajerial, Kepemilikan Institusional, Risiko, Kebijakan Utang dan Kebijakan Dividen: Analisis Persamaan Simultan, Tesis, Pascasarjana Universitas Gadjah Mada.

Ismiyanti, F., 2007, Biaya Keagenan pada Mikrostruktur Pasar: Pende- 
katan Rentang Harga, Disertasi, Pascasarjana Universitas Gadjah Mada.

Ismiyanti, F. dan Putu Anom Mahadwartha, 2008, Does Debt Affect Firm Financial Performance? The Role of Debt on Corporate Governance: Evidence from Indonesia, Jurnal Riset Akuntansi Indonesia.

Iturriaga, Felix J. Lopez and Vicente Lima Crisostomo, 2010, Do Leverage, Dividend Payout and Ownership Concentration Influence Firms Value Creation? An Analysis of Brazilian Firms, Emerging Market Finance \& Trade, 46, page 80-94.

Jelinek and Stuerke, 2009, The Nonlinear Relation Between Agency Costs and Managerial Equity Ownership, Evidence of Decreasing Benefits of Increasing Ownership, International Journal of Managerial Finance, Vol. 5, No. 2, page 156178.

Jensen, M. C. and W. H. Meckling, 1976, Theory of the Firm: Managerial Behavior, Agency Cost, and Ownership Structure, Journal of Financial Economic, 3, page 305-360.

Jensen, M. C., 1986, Agency Costs of Free Cash Flow, Corporate Finance, and Takeovers, American Economic Review, 76, page 323329.

Jensen, Michael C. and Kevin J. Murphy, 1990, Performance Pay and Top-Management Incentives, Journal of Political Economy, page $1-52$.
Jensen, G. R., D. P. Solberg and T.S. Zorn, 1992, Simultaneous Determination of Insider Ownership, Debt, and Dividend Policies, Journal of Financial and Quantitative Analysis, 27, page 247-263.

Jensen, M. C., 1993, The Modern Industrial Revolution, Exit and The Failure of Internal Control Systems, Journal of Finance, 48, page 831-880.

Jian, Ming Jane and T. J. Wong, 2010, Propping and Tunneling Throught Related Party Trasaction, Review of Accounting Studies.

Jiang, Li and Jeong-Bon Kim, 2000, Cross-Corporate Ownership, Information Asymmetry and the Usefulness of Accounting Performance Measures in Japan, International Journal of Accounting, page 85-98.

Joh, Sung Wook, 2003, Corporate Governance and Firm Profitability: Evidence from Korea Before The Economic Crisis, Journal of Financial Economic, 68, page 287-322.

Johnson, Simon, Peter Boone, Alasdair Breach and Eric Friedman, 2000, Corporate Governance in Asian Financial Crisis, Journal of Financial Economic, 58, page 141-186.

Kallapur, S. and M. A. Trombley, 1999, The Association Between Investment Opportunity Set Proxies and Realized Growth, Journal of Business Finance and Accounting, 26, page 505-519.

Kim, S. W. and E. H. Sorenson, 1986, Evidence on The Impact of The Agency Cost of Debt on Corporate Debt Policy, Journal of 
Financial and Quantitative Analysis, 21, page 131-144.

Kim, Rhim and Friesner, 2007, Interrelationships Among Capital Structure, Dividens, and Ownership: Evidence from South Korea, The Multinational Business Review, Vol. 15, No. 3.

Klapper, Leora F. and Inessa Love, 2004, Corporate Governance, Investor Protection and Performance in Emerging Markets, Journal of Corporate Finance, 10, page 703728.

Klaus Gugler and B. Burcin Yurtoglu, 2002, Corporate Governance and Dividend Pay-out Policy in Germany, European Economic Review, 47, page 731-758.

Kouki and Said, 2011, Does Management Ownership Explain The Effect of Leverage on Firm Value? An Analysis of French Listed Firms, Journal of Business Studies Quarterly, Vol. 3, No. 1, page 169186.

Kraus, Alan and Robert $\mathrm{H}$. Litzenberger, 1973, A State-Preference Model on Optimal Financial Leverage, Journal of Finance, 28, page 911-922.

Kuan, Ruth Tan Seow, Chng Pheng Lui and Tan Tee Ween, 2000, CEO Share Ownership and Firm Value, Working Paper, August 11, Department of Finance and Accounting, Faculty of Business Administration, National University of Singapore 17, Law Link, Singapore 117591.

Lang, Larry H. P., Eli Ofek and Rene M. Stulz, 1996, Leverage, Invest- ment, and Firm Growth, Journal of Financial Economics, Vol. 40, No. 1, page 3-29.

La Porta, R., F. Lopez-de-Silanes, A. Shleifer and R. W. Vishny, 1998, Law and Finance, Journal of Political Economy, 106, page 1113-1155.

La Porta, R., F. Lopez-De-Salines and A. Shleifer, 1999, Corporate Ownership Around The World, Journal of Finance, LIV/2, page 471-517.

La Porta, R., Florencio Lopez-DeSialanes, Andrei Shleifer and Robert Vishny, 2002, Investor Protection and Corporate Valuation, Journal of Finance, 57, (3), page 147-1170.

Lee Sanghoon, 2008, Ownership Structure and Financial Performance: Evidence from Panel Data of South Korea, Forthcoming in Corporate Ownership and Control, Vol. 6, No. 2.

Lemmon, Michael and Karl V Lins, 2003, Ownership Structure, Corporate Governance and Firm Value: Evidence from East Asian Financial Crisis, Journal of Finance, 58, (4), page 1445-1468.

Lin, Feng-Li and T. Chang, 2008, Does Ownership Concentration Affect Firm Value in Taiwan? A Panel Threshold Regression Analysis, Empirical Economics Letters, 7, page 673-680.

Long, John and Heen Malitz, 1985, Investment Patterns and Financial Leverage, in Benjamin Friedman, Ed.: Corporate Capital Structure in 
The United States (The University of Chicago Press, Chicago).

Mahadwartha, Putu Anom, 2004, Pengawasan dan Pengikatan Berbasis Kepemilikan Institusional Internal, Disertasi, Pascasarjana Universitas Gadjah Mada.

Maloney, M. T., R. E. McCormick and M. L. Mitchell, 1993, Managerial Decision Making and Capital Structure, Journal of Business 66, page 189-217.

McConnell, John J. and Henri Servaes, 1995, Equity Ownership and The Two Faces of Debt, Journal of Financial Economics, 39, page 131157.

Megginson, W. L., 1997, Corporate Finance Theory, Addison-Wesley Educational Publishers Inc.

Modigliani, F. and M. Miller, 1958, The Cost of Capital, Corporate Finance and The Theory of Investment, American Economic Review, 53, page 433-443.

Modigliani, F. and M. Miller, 1963, Corporate Income Tax and the Cost of Capital: A Correction, American Economic Review, page 433-443.

Morck, Randall, Andrei Shleifer and Robert W. Vishny, 1988, Management Ownership and Market Valuation: An Emphirical Analysis, Journal of Financial Economics, 20, page 293-315.

Murphy, Kevin J., 1985, Corporate Performance and Managerial Remuneration: An Empirical Analysis, Journal of Accounting and Economics, 7, page 11-42.
Myers, S. C., 2003, Financing of Corporations, in G. Constantinides, M. Harris and R. Stulz (Eds.), Handbook of the Economics of Finance: Corporate Finance, Amsterdam, North Holland: Elsevier, page 215-253.

Pedersen, Torben and Steen Thomsen, 2001, The Causal Relationship Between Insider Ownership, Owner Identity and Market Valuation Among The Largest European Companies, Working Paper Series WP 15-2001, Departement of International Economics and Management Copenhagen Business School, Howitzvej 60, 2000 Copenhagen F.

Peraturan Bapepem Nomor IX.I.7 tentang Pembentukan dan Pedoman Penyusunan Piagam Unit Audit Internal oleh Emiten dan Perusahaan Publik, November 2008.

Pouraghajan, Tabari, Mansourinia and Emamgholipour, 2013, Investigation the Effect of Financial Ratios, Operating Cash Flows and Firm Size on Earnings Per Share: Evidence from the Tehran Stock Exchange, International Research Journal of Applied and Basic Sciences.

Pusher, George M., 1995, Equity Ownership Structure, Leverage and Productivity: Emphirical Evidence from Japan, Pacific Basin Finance Journal, 3, page 214-255.

Rajan, R. G. and L. Zingales, 1995, What Do We Know about Capital Structure? Some Evidence from International Data, Journal of Finance, 50, page 1421-1460. 
Ram Mudambi and Carmela Nicosia, 1998, Ownership Structure and Firm Performance: Evidence from UK Financial Services Industry, Applied Financial Economics, 8, page $175-180$.

Rayan, Kuben, 2008, Financial Leverage and Firm Value, A Research Project Gordon Institute.

Ross, S., R. W. Westerfield and J. Jaffe, 1999, Corporate Finance, 5th Edition, Irwin McGraw-Hill, page 407.

Ruan, Tian and Ma, 2011, Managerial Ownership, Capital Structure and Firm Value: Evidence from China's Civilian-run Firms, Australasian Accounting Business and Finance Journal, Vol. 5, No. 3, page 73-92.

Sabiswalsky, R., 2010, Nonlinear Modeling of Target Leverage with Latent Determinant Variables New Evidence on The Trade-off Theory, Review of Financial Economics, 19 , page $137-150$.

Shleifer, A. and R. W. Vishny, 1986, Large Shareholders and Corporate Control, Journal of Political Economy, 94, page 461-488.

Shleifer, A. and R. W. Vishny, 1997, A Survey of Corporate Governance, Journal of Finance, 52, page 737783.

Short, H. and K. Keasey, 1999, Managerial Ownership and The Performance of Firms: Evidence from the UK, Journal of Corporate Finance, 5, page 79-101.

Singh. M. and Davidson III W. N., 2003, Agency Cost, Ownership Structure and Corporate Gover- nance Mechanism, Journal of Banking and Finance, 27, page 793816.

Siregar, B., 2006, Pemisahan Hak Aliran Kas dan Hak Kontrol dalam Struktur Kepemilikan Ultimat, Yogyakarta, Universitas Gadjah Mada.

Smith, C. and R. Watts, 1992, The Investment Opportunity Set and Corporate Financing, Dividend and Compensation Policies, Journal of Financial Economics, 32, page 263292.

Stephen and David, 2009, Why Capital Efficiency Measures Are Rarely Used In Incentive Plans, and How to Change That, Journal of Applied Corporate Finance, Vol. 21, page 87-92.

Stulz, R., 1990, Managerial Discretion and Optimal Financing Policies, Journal of Financial Economics, 26, page 3-27.

Sulong, Z. and F. M. Nor, 2010, Corporate Governance Mechanisms and Firm Valuation in Malaysian Listed Firms: A Panel Data Analysis, Journal of Modern Accounting and Auditing, 6, page 1-19.

Surya dan Yustiavandana, 2006, Penerapan Good Corporate Governance: Mengesampingkan Hak-Hak Istimewa Demi Kelangsungan Usaha, Kencana Jakarta.

Thomsen, S., 2004, Blockholder Ownership, Dividends, and Firm Value in Continental Europe, Department of International Economics and Management, Copenhagen Business School. 
Tsuji, Chikashi, 2011, A Survey of The Trade-off Theory of Corporate Financing, Business Management Review, 1, (6), page 102-107.

Ugurlu, Mine, 2000, Agency Costs and Corporate Control Devices in The Turkish Manufacturing Industry, Journal of Economic Studies, Vol. 27, No. 6, page 566-599.

Wang, George Yungchih, 2010, The Impacts of Free Cash Flows and Agency Costs on Firm Performance, Journal Service Science \& Management, 3, page 408-418.

Wellalege and Locke, 2011, Ownership Structure and Firm Financial Performance: Evidence from Panel Data in Sri Lanka, Journal of Business Systems, Governance and Ethics, Vol. 7, No. 1.

Wiwattanakantang, Y., 2001, Controlling Shareholders and Corporate Value: Evidence from Thailand, Pacific-Basin Finance Journal, 9, page 323-362.
Wolfenzon, D., 1999, A Theory of Piramidal Structures, Working Paper, Harvard University.

Yeh, Y. H., 2005, Do Controlling Shareholders Enhance Corporate Value?, Corporate Governance: An International Review of Finance, 2, page 21-48.

Yuliani, Isnurhadi dan Samardi W. Bakar, 2013, Keputusan Investasi, Pendanaan, dan Dividen Terhadap Nilai Perusahaan Dengan Risiko Bisnis Sebagai Variabel Mediasi, Jurnal Keuangan dan Perbankan, Vol. 17, No. 3, hal 362-375.

Zeitun and Tian, 2007, Does Ownership Affect A Firm's Performance and Default Risk in Jordan?, The International Journal of Business in Society, Vol. 7, No. 1 , page 66-82. 